since the Second World War. The editor, M. J. Georges, signalizes the present epoch as one in which pure science steps down from its academic seat and mingles with the workers in industry. $\mathrm{He}$ rightly senses that the latter have not at present the leisure to delve into the specialized journals in the hope of finding scientific facts that they may apply in their work. The moment should, therefore, be propitious to launch a review which will let the technician know what is being done in applied physies-more particularly in electricity - and chemistry in language which, without despising the formula and the diagram, should be readily understood by him. The first number contains articles on the electrification schemes of the Belgian railways, a new thermodynamic cycle, motors for aircraft, the manufacture of photographic films, and the applications of thermionic valves - all, with one exception, by Belgian authors. They seem well written from the point of view of the reader, particularly of the young technologist in industry, and are calculated to show him the wide range which physical science now covers in its applications. In welcoming this new periodical, we note with interest that it is hoped soon to issue a version for English-speaking readers, as well as translations in Dutch and German, and to enlist the collaboration of men of science outside Belgium.

\section{The New Naturalist}

LIKE the second, the sixth number of the recently launched journal, The New Naturalist, is devoted to a natural region of the British Isles; then, it was the Western Isles of Scotland, and now, in contrast, East Anglia. The multiplicity and complexity of the fauna and flora of the Broads and the Breck, marshes and the meres, swamps and shores of Norfolk and Suffolk have long made them the home of many of Britain's most enthusiastic naturalists. Natural history societies were formed and working in Norfolk long before they had appeared in most other parts of Britain, and it is not surprising, therefore, that this issue of The New Naturalist should be of high standard. Prof. Darby, the fens historian, and J. N. Jennings and J. M. Lambert describe how the country has been changed by man, while Prof. J. A. Steers discusses geological changes in the coast-line. E. A. Ellis and Dr. A. S. Watt consider the natural history of the Broads and the Breck, while the special problems presented to students by a group like the rushes are elaborated by Dr. Paul Richards. Two wellknown naturalist families in East Anglia are represented by the late Dr. R. Gurney and Major A. Buxton, who write about aquatic life in the Norfolk Broads and sportsmen's activities in Norfolk respectively. Dr. E. A. R. Ennion shows how much Flatford Mill Field Centre is contributing to the development of natural history studies in East Anglia, and Dr. D. Lack introduces an ornithological examination paper which was recently 'set' at a social evening in Oxford and which should provide many ornithologists with much diversion but few marks. The illustrations have been chosen with keen discrimination and executed to give delight to all who see them.

\section{Horticulture of Aroid 'Lilies'}

The American Plant Life Society has devoted Volume 4 of "Plant Life", its year-book for 1948 (Stanford, Calif. ; n.p.), to the aroid or calla 'lilies'. Chief among the various regional and floristic papers is a detailed description of species of the genus
Zantedeschia, by Dr. Hamilton P. Traub. This genus was proposed by Sprengel in 1826, to accommodate the South African species of the Linnæan genus Calla. Eight species are described in detail, with illustrations, and many garden forms and hybrids are also mentioned. A key is provided, and horticulturalists should find much useful knowledge in this paper.

\section{Scientific Papers Published in the Middle East}

The fourth number of the "List of Scientific Papers published in the Middle East" (pp. 72; Cairo : Unesco Science Co-operation Office, Middle East, November 1949) appeals for the co-operation of all men of science in the Middle East to make the List a really complete bibliography by directing attention to occasional scientific publications, irregular series and books published in the region and assisting in obtaining copies. In principle, this publication contains only original works, or works with original data, of value to scientific workers, and the present number covers the period March 15-October 1, 1949. It is arranged on the same lines as previously : a list of periodicals and serials, arranged by countries, preceding the list of scientific papers arranged by Universäl Decimal Classification classes.

\section{Mathematical Periodicals for Yenching University}

Prof. E. R. LAPwood, of the Department of Mathematics, Yenching University, Peking, writes on behalf of the University asking for help in filling gaps in the library. He asks particularly for sets of the Proceedings and Journal of the London Mathematical Society before 1939, and one or two later numbers; also for volumes of the Mathematical Gazette before 1920 and various subsequent numbers. Mr. E. Cunningham, 141 Huntingdon Road, Cambridge, acting for the China Christian Universities' Association, would be glad to hear from any who could help to supply these needs.

\section{Botanical Society of the British Isles: Conference}

ThE Botanical Society of the British Isles is organising a conference on "Aims and Methods in the Study of the Distribution of British Plants", to be held during March 31-April 2 in the lecture room of the Royal Horticultural Society's New Hall, Greycoat Street, Westminster, London, S.W.1. April 2 will be devoted to a field meeting in Quendon Woods, Essex, to study the oxlip (Primula elatior). The conference will be preceded by the annual general meeting of the Society on March 30 at $5.30 \mathrm{p.m}$. in the rooms of the Linnean Society, Burlington House, Piccadilly, London, W.1. All inquiries regarding these meetings should be addressed to the Honorary General Secretary of the Society, c/o Department of Botany, British Museum (Natural History), Cromwell Road, London, S.W.7.

\section{Rheological Problems in Biology}

AN international colloquium on rheological problems in biology (see Nature, December 24, 1949, p. 1078) will be held in Lund during July 26-28, and sessions will be devoted to general properties of protoplasm, mechanics of muscular contraction, flow of blood, and translocation of nutrients in plants. Since the object of the colloquium is the exchange of ideas between biologists of widely different fields of work, it is desirsble that communications should be of a fairly general character and need not deal wholly with recent and unpublished. 